\title{
Recombinant human complement component C2 produced in a human cell line restores the classical complement pathway activity in-vitro: an alternative treatment for $\mathrm{C} 2$ deficiency diseases
}

\author{
Paolo GV Martini ${ }^{1 *}$, Lynette C Cook ${ }^{1}$, Scott Alderucci ${ }^{1}$, Angela W Norton', Dianna M Lundberg ${ }^{1}$, Susan M Fish', \\ Knut Langsetmo', Göran Jönsson², Christian Lood ${ }^{3}$, Birgitta Gullstrand ${ }^{3}$, Kate J Zaleski ${ }^{4}$, Nancy Saviolii, \\ Jason Lottherand ${ }^{4}$, Charles Bedard ${ }^{5}$, John Gill ${ }^{5}$, Michael F Concino ${ }^{1}$, Michael W Heartlein ${ }^{6}$, Lennart Truedsson ${ }^{3}$, \\ Jan L Powell ${ }^{4}$, Arthur O Tzianabos ${ }^{6}$
}

\begin{abstract}
Background: Complement C2 deficiency is the most common genetically determined complete complement deficiency and is associated with a number of diseases. Most prominent are the associations with recurrent serious infections in young children and the development of systemic lupus erythematosus (SLE) in adults. The links with these diseases reflect the important role complement C2 plays in both innate immunity and immune tolerance. Infusions with normal fresh frozen plasma for the treatment of associated disease have demonstrated therapeutic effects but so far protein replacement therapy has not been evaluated.

Results: Human complement C2 was cloned and expressed in a mammalian cell line. The purity of recombinant human C2 (rhC2) was greater than 95\% and it was characterized for stability and activity. It was sensitive to C1s cleavage and restored classical complement pathway activity in C2-deficient serum both in a complement activation ELISA and a hemolytic assay. Furthermore, rhC2 could increase C3 fragment deposition on the human pathogen Streptococcus pneumoniae in C2-deficient serum to levels equal to those with normal serum.

Conclusions: Taken together these data suggest that recombinant human C2 can restore classical complement pathway activity and may serve as a potential therapeutic for recurring bacterial infections or SLE in C2-deficient patients.
\end{abstract}

\section{Background}

Our understanding of the role of complement in human disease is the result of numerous studies in recent years focused on complement's mechanism of action. This has resulted in achieving important information on the role of complement as a major mediator and effector mechanism in diseases of immune and non-immune pathogenesis. Complement is not only important for protection against microorganisms, but also contributes to the pathophysiology of a number of autoimmune diseases.

\footnotetext{
* Correspondence: pmartini@shire.com

'Department of Protein Expression and Purification Research, Shire Human

Genetic Therapies Inc., 700 Main Street, Cambridge, MA 02139, USA

Full list of author information is available at the end of the article
}

Progress regarding the biological role of complement has been made by studying disease associations in patients with inherited complement protein deficiencies [1]. Genetic deficiencies of complement components are a common denominator of immune and infectious diseases. Deficiencies of complement components of the classical activation pathway, C1, C2 and C4, all lead to increased susceptibility to bacterial infections [2] and increased risk of developing autoimmune disease, particularly systemic lupus erythematosus (SLE) [3]. The complement system consists of more than 30 soluble and membrane proteins and constitutes an important mediator of host defense against foreign pathogens. Complement component $\mathrm{C} 2$ functions as a key regulator 
in the early activation phase of the classical pathway and participates in the formation of the classical pathway C3 convertase C4b2a [4]. C2 is also a critical component of the lectin pathway. Specifically, when mannose-binding lectin (MBL) or ficolins in complex with MBL-associated serine protease (MASP) molecules bind to relevant carbohydrate molecules, this leads to activation of MASP-2 which then may cleave both $\mathrm{C} 2$ and C4 thereby forming the same C3 convertase as in classical pathway activation [5]. Thus, C2 is an important component of both the classical and the lectin pathways of complement activation and is involved in first line defense against microbial infection that is essential for detection and clearance of the invading pathogens [6].

Complement $\mathrm{C} 2$ deficiency is the most common genetically determined complete complement deficiency with a prevalence estimated to be approximately 1:20,000 in individuals of Caucasian ancestry [3], making it a clinically important immune deficiency [7]. The deficiency is, in the majority of cases, caused by homozygosity for $\mathrm{C} 2$ genes having deletions in exon 6 , resulting in complete absence of $\mathrm{C} 2$, or in some cases caused by other $\mathrm{C} 2$ gene mutations $[8,9]$

The alternative activation pathway, which is C3 dependent, is generally intact in C2 deficiency and can trigger formation of the membrane attack complex (MAC) independently of C2 [4]. However, in the absence of $\mathrm{C} 2, \mathrm{C} 3$ is, in many situations, not efficiently cleaved resulting in a limited deposition of C3 fragments on immune complexes and on the surface of apoptotic cells. Circulating apoptotic cells become a source of self antigen for auto-antibodies that participate in the formation of immune complexes. The immune complexes are deposited throughout the body, potentially causing localized inflammatory reactions in joints and kidneys, and ultimately leading to renal disease from chronic activation of the complement system [10].

In this study, we considered $\mathrm{C} 2$ replacement as a therapeutic target to explore the feasibility of restoring the complement pathway in cases of $\mathrm{C} 2$ deficiency. It has been previously proposed that purified human $\mathrm{C} 2$ could restore classical and lectin complement pathways and hemolytic activity ex-vivo in serum collected from C2deficient patients [11]. Two case histories have been described where regular infusions of fresh frozen plasma were beneficial in patients with C2-deficiency and SLE; this benefit was ascribed to the $\mathrm{C} 2$ contained in the fresh frozen plasma $[12,13]$. Therefore, we hypothesized that recombinant human complement component $\mathrm{C} 2$ (rhC2) could restore complement activity in serum from C2-deficient patients. To test this hypothesis we have expressed and purified rhC2 and assessed complement activation in vitro. To our knowledge this is the first report of proof of concept for treating C2 deficiency with recombinant human $\mathrm{C} 2$.

\section{Results \\ Protein Cloning and Expression}

The rhC2 was highly expressed in human cells and shown to be purified very efficiently by a 2-step column chromatography process (Figure 1A) based on a modification and improvement of a procedure previously described [14,15] (some cleaved products of $\mathrm{rhC} 2, \mathrm{C} 2 \mathrm{a}$ and $\mathrm{C} 2 \mathrm{~b}$, are present in the conditioned media as a result of endogenous proteases produced by the cells). After purification, a major band, representing $\mathrm{rhC} 2$, is visible by Coomassie staining as well as a smaller band, $\mathrm{C} 2 \mathrm{~b}$, the inactive part of the cleaved $\mathrm{C} 2$, which co-purifies with the full length protein and constitutes a minor impurity. $\mathrm{C} 2 \mathrm{a}$ is completely removed during the purification process. An early report on $\mathrm{C} 2$ analysis indicates that the mature protein has eight glycosylation sites [16]. To determine post-translational modification of rhC2 we performed a glycodigestion with Peptide $\mathrm{N}$ glycosidase and show that rhC2 is glycosylated when produced in human cells (Figure 1B). Neuramidase digestion of the protein also demonstrated the presence of sialic acid on rhC2 (Figure 1C), which may result in greater stability of the protein in serum [17]. By multi angle static light scattering (MALS) the weight average molar mass $\left(\mathrm{M}_{\mathrm{w}}\right)$ of the full length $\mathrm{rhC} 2$ including glycosylation was determined to be $99,800 \mathrm{~g} / \mathrm{mol}$ (Figure 2). The number average molar mass $\left(M_{n}\right)$ can also be determined by SEC-MALS, with the ratio $M_{w} /$ $\mathrm{M}_{\mathrm{n}}$ providing a measure of polydispersity. The polydispersity index of rhC2 is 1.00054, indicating narrow mass distribution. The line in figure 2 represents the differential refractive index (dRI) versus elution time, indicating the elution of rhC2. The data points in figure 2 are the molar mass determined from the light scattering intensity using the concentration measured by dRI for the glycoprotein complex, and the absorbance at $280 \mathrm{~nm}$ for the protein component. The molar mass of the protein component was $84,000 \mathrm{~g} / \mathrm{mol}$ and the difference in the two masses was the weight of the modifiers (glycosylation) which was $15,800 \mathrm{~g} / \mathrm{mol}$. The $84,000 \mathrm{~g} / \mathrm{mol}$ mass of the protein without any modifiers was consistent with the expected molecular weight calculated from the protein sequence of $\sim 82000 \mathrm{kDa}$. The purity of $\mathrm{rhC} 2$ determined by size exclusion chromatography (SEC) was greater than 95\% (Figure 3A) with minor impurities consisting mainly of $\mathrm{C} 2 \mathrm{~b}$, characterized also by MALDITOF analysis (data not shown).

Differential scanning calorimetry (DSC) showed a single temperature induced unfolding transition with a temperature midpoint $\left(\mathrm{T}_{\mathrm{m}}\right)$ of $53.4^{\circ} \mathrm{C}$ (Figure $3 \mathrm{~B}$ ). The ratio of the 


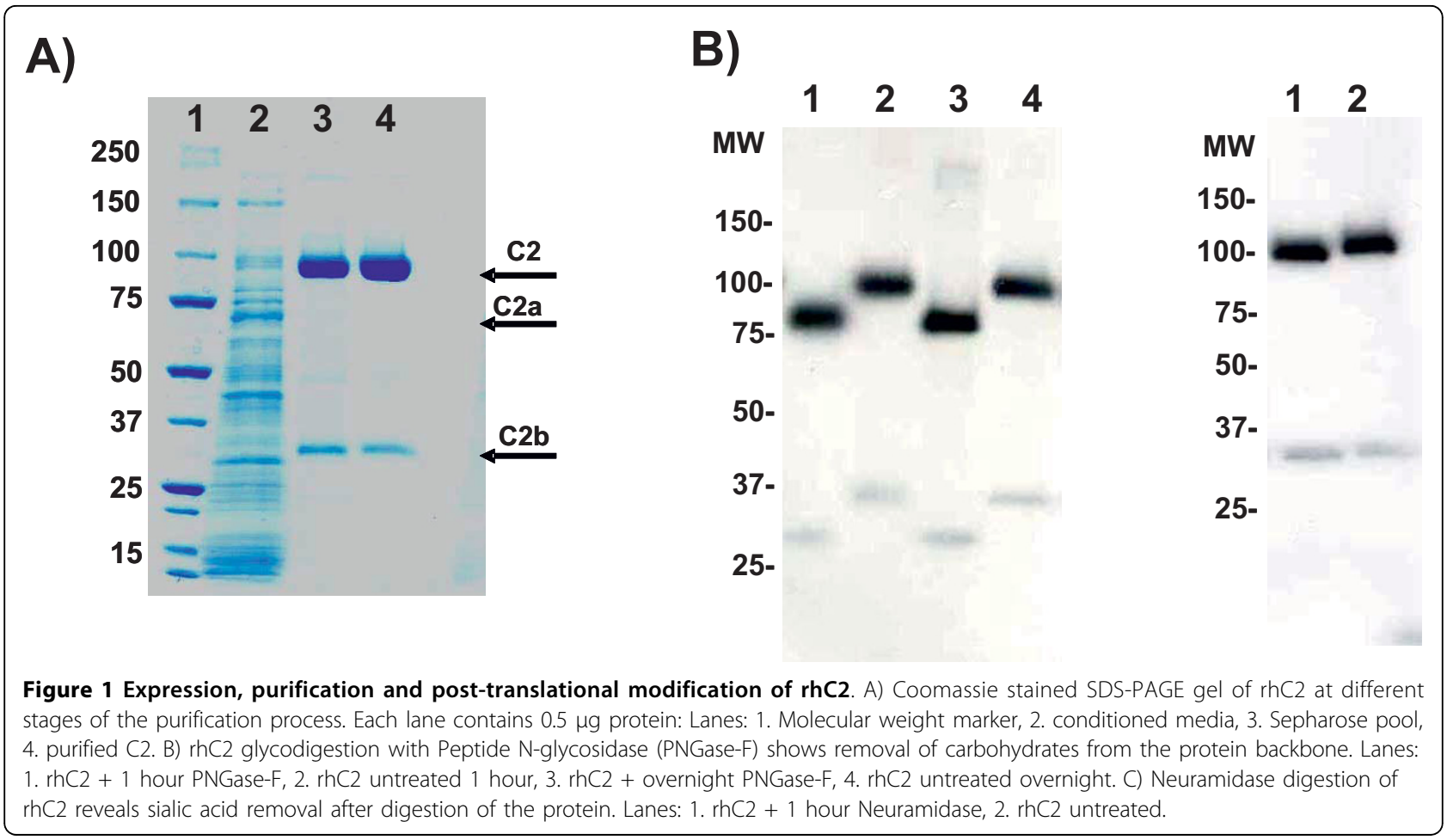

calorimetric enthalpy $\left(\Delta \mathrm{H}_{\text {cal }}\right)$ to the van't Hoff enthalpy $\left(\Delta \mathrm{H}_{\mathrm{vH}}\right)$ was 2.8 , consistent with the three structural domains of rhC2 unfolding in a single transition. Surveys comparing $\mathrm{T}_{\mathrm{m}}$ and $\Delta \mathrm{H}$ at various $\mathrm{pH}$ values and salt concentrations indicate that rhC2 is most stable at $\mathrm{pH} 6.5$ and $150 \mathrm{mM} \mathrm{NaCl}$ (data not shown).

rhC2 is cleaved by $\mathrm{C} 1 \mathrm{~s}$ and is active in $\mathrm{C} 2$ depleted serum As a first step in the activation of the classical complement pathway, complement protein $\mathrm{C} 1 \mathrm{q}$ binds to antibodies and triggers the activation of $\mathrm{C} 1 \mathrm{r}$ and $\mathrm{C} 1 \mathrm{~s}$. Activated complement factor $\mathrm{C} 1$ s cleaves $\mathrm{C} 2$ and $\mathrm{C} 4$ so they can form the $\mathrm{C} 3$ convertase thereby triggering the terminal portion of the complement cascade [15]. Therefore, in order for $\mathrm{C} 2$ to be fully functional, it must first be cleaved by $\mathrm{C} 1 \mathrm{~s}$. Cleavage of $\mathrm{C} 2$ results in release of $\mathrm{C} 2 \mathrm{a}(70 \mathrm{kDa})$ which in association with $\mathrm{C} 4 \mathrm{~b}$ serves as the $\mathrm{C} 3$ convertase. A smaller protein, C2b $(30 \mathrm{kDa})$, is also released following cleavage by $\mathrm{C} 1 \mathrm{~s}$. To determine that rhC2 exhibited the correct functional conformation, purified protein was incubated with purified $\mathrm{C} 1 \mathrm{~s}$ and the resultant proteins visualized by SDS-PAGE and Coomassie staining (Figure 4A). Results from these studies show that $\mathrm{rhC} 2$ is cleaved by $\mathrm{C} 1 \mathrm{~s}$, releasing $\mathrm{C} 2 \mathrm{a}$ and $\mathrm{C} 2 \mathrm{~b}$ proteins of the correct molecular weight. C2 purified from human plasma was included as a positive control. These data suggest that $\mathrm{rhC} 2$ forms the correct functional conformation to activate the classical complement pathway.
To determine whether rhC2 was able to restore complement activation through the classical pathway, purified recombinant protein was diluted in affinity depleted C2-deficient serum $(0-40 \mu \mathrm{g} / \mathrm{ml})$ and tested using the Total Complement (3-Pathway) ELISA. The 3-pathway ELISA measures the ability of complement proteins in a given serum sample to activate the classical, lectin or alternative pathway based on specific antigens used to trigger each pathway of the cascade. Results show the specific reconstitution of the classical and lectin complement pathways when $\mathrm{rhC} 2$ was added to the C2depleted serum but these pathways were not activated in the absence of rhC2 (Figure 4B). An rhC2 concentration of $3 \mu \mathrm{g} / \mathrm{ml}$ restored $>50 \%$ classical pathway activity, with $100 \%$ activation at $12 \mu \mathrm{g} / \mathrm{ml}$. As expected, the alternative pathway, which is independent of $\mathrm{C} 2$, was activated by $\mathrm{C} 2$-depleted serum. An irrelevant protein (a transferrin fusion protein) with similar MW was used as negative control and did not activate the complement pathway.

\section{C3 deposition on bacterial pathogen Streptococcus pneumoniae}

Susceptibility to encapsulated bacterial pathogens such as Streptococcus pneumoniae, Neisseria meningitidis and Haemophilus influenzae is a hallmark of $\mathrm{C} 2$ deficiency, particularly in young children ( $\leq 2$ years) (2). The classical complement pathway plays a key role in the clearance of these pathogens through antibody and 


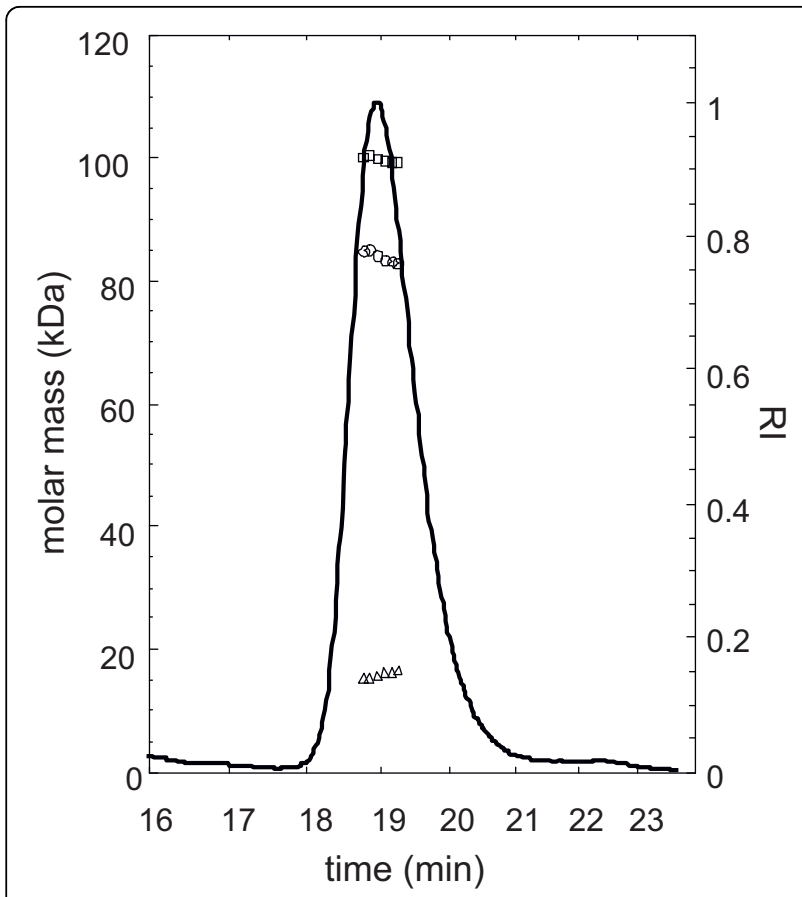

Figure 2 Analysis of rhC2 glycosylation by SEC-MALS. rhC2 was eluted from a Tosoh Super SW3000 size exclusion column and monitored by normalized differential refractive index $(-)$ and absorbance at $280 \mathrm{~nm}$ versus time. Molar mass was analyzed by multi angle light scattering following the total mass by differential refractive index ( $\square$ ), and protein mass by absorbance at $280 \mathrm{~nm}(\mathrm{O})$. The molar mass contributed by glycosylation is plotted as the difference between the total mass and the mass of the protein $(\boldsymbol{\Delta})$. The average molar mass determined for the total is $99.8 \mathrm{kDa}$, the protein $84 \mathrm{kDa}$, and the carbohydrate $15.8 \mathrm{kDa}$. non-antibody-mediated mechanisms. Complement activation by antibodies to encapsulated bacterial pathogens results in the deposition of $\mathrm{C} 3 \mathrm{~b}$ on the surface of the bacterium in association with $\mathrm{C} 3$ cleavage by the C4b2a complex. In the absence of $\mathrm{C} 2$, only $\mathrm{C} 4 \mathrm{~b}$ is bound to the bacterial cells as a result of the classical pathway activation initiated by the specific antibodies. The addition of $25 \mu \mathrm{g} / \mathrm{ml} \mathrm{rhC} 2$ or $\mathrm{C} 2$ purified from plasma to $\mathrm{C} 2$-deficient serum increased the C3d deposition on Streptococcus pneumoniae to levels similar to those using a pool of normal serum (Figure 5A). Thus, we could demonstrate that addition of $\mathrm{C} 2$ to C2-deficient serum highly increased the C3 fragment deposition on the bacteria. Figure 5B shows flow cytometry plot of $\mathrm{C} 3$ fragment deposition using a serum sample from a C2-deficient patient serum before and after restitution with rhC2

\section{Reconstitution of classical pathway activity in serum from C2-deficient patients}

Considering $\mathrm{rhC} 2$ as a therapeutic alternative for $\mathrm{C} 2$ deficiency-associated diseases, it was important to test the concept in serum collected from human patients homozygous for C2 deficiency. We have used the 3-pathway ELISA that measures complement cascade activation as well as a hemolytic assay that measures classical pathway activity by determining the ability of serum complement proteins to bind to antibody-coated sheep red blood cells. Successful activation of the classical pathway results in formation of the MAC and red

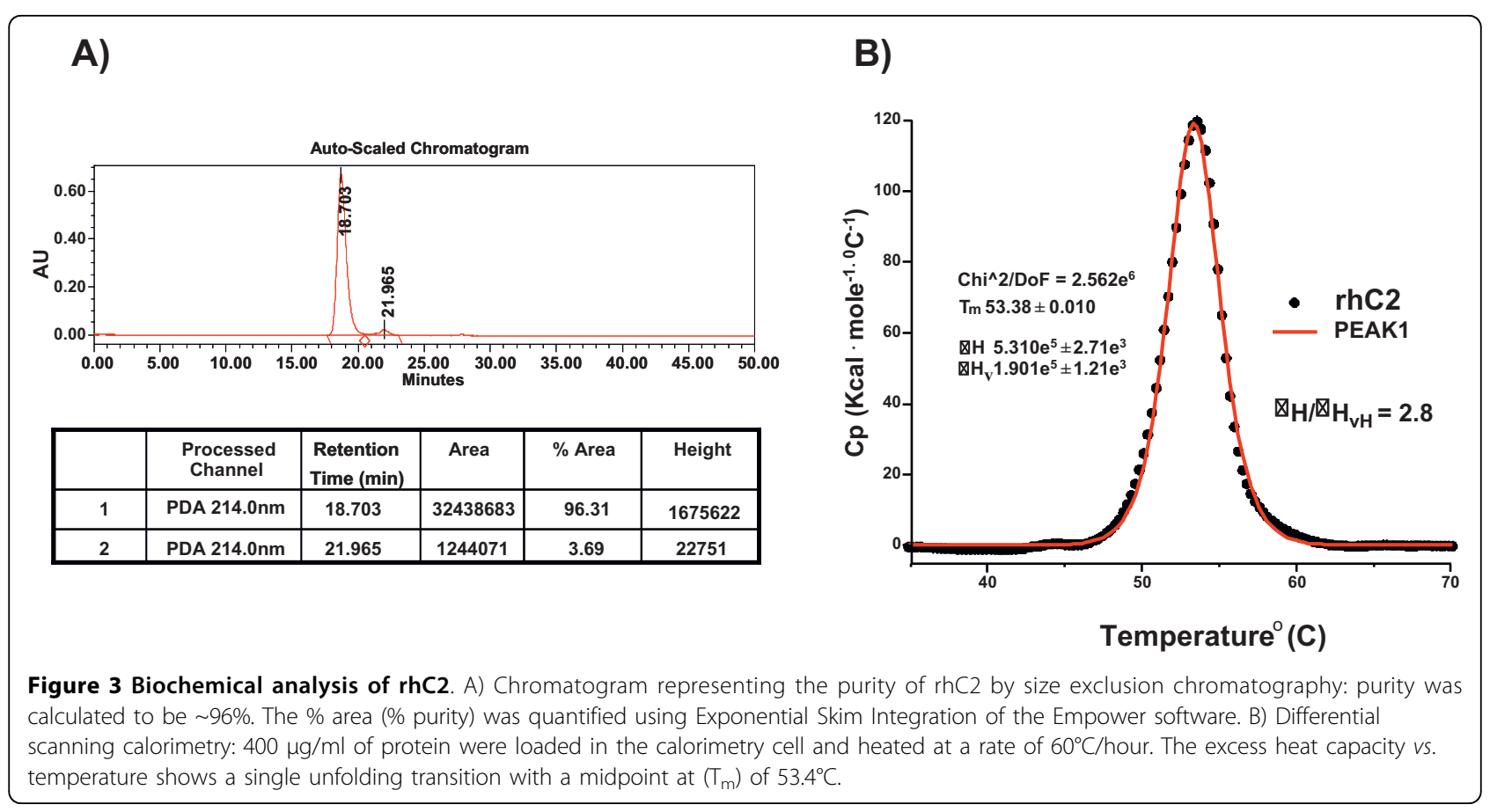




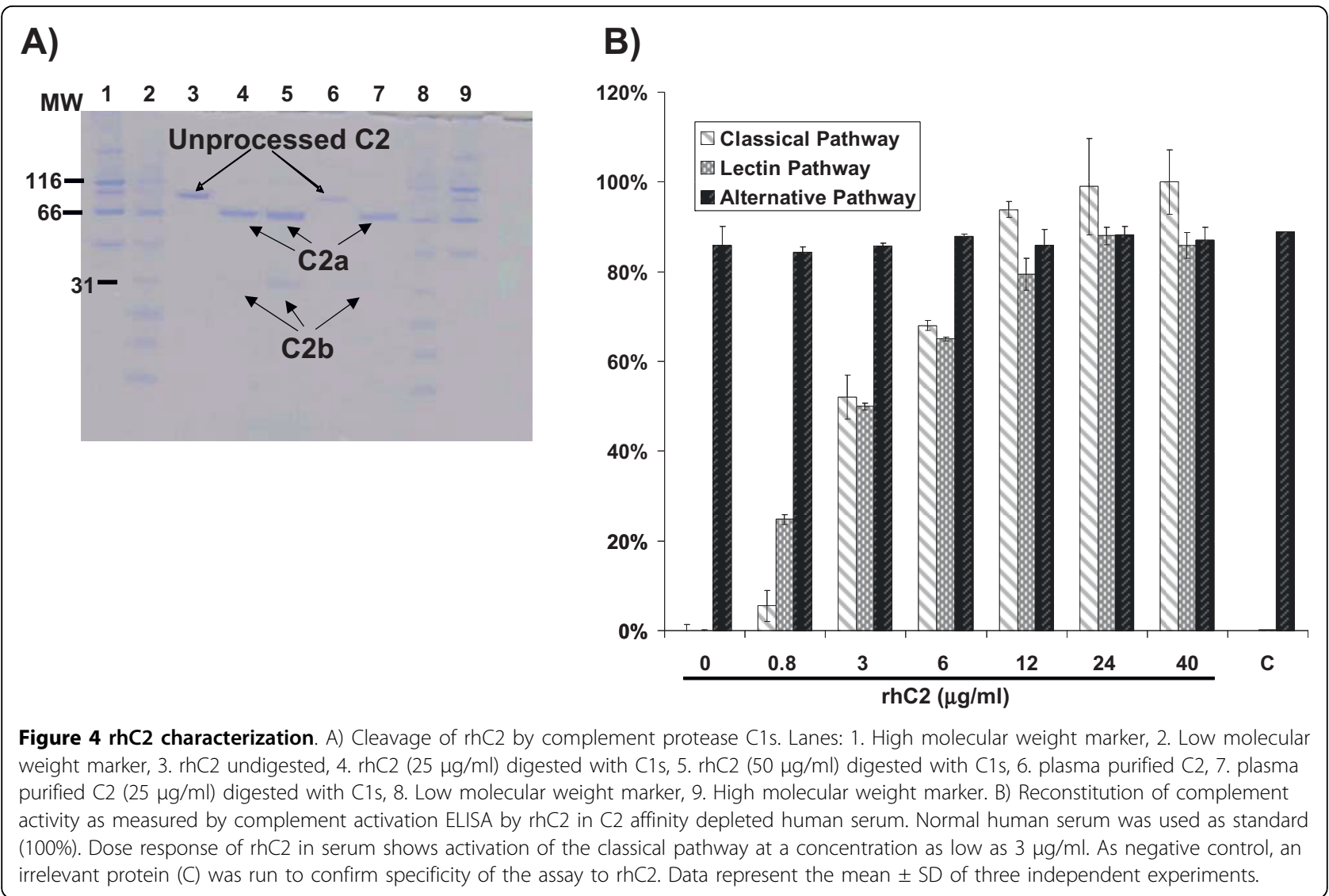

blood cell lysis. Serum from six different C2-deficient patients was reconstituted with $\mathrm{rhC} 2$ and tested in the 3-pathway ELISA according to the manufacturer's instructions and three $\mathrm{C} 2$-deficient sera were also analyzed by the hemolytic assay [18]. In addition, rhC2 was titrated and tested in $\mathrm{C} 2$-deficient serum from patients in the 3-pathway ELISA to investigate the minimum amount of protein needed to restore classical pathway activity to levels similar to those in pooled normal human serum.

Results from the 3-pathway ELISA and hemolytic assay show that $\mathrm{rhC} 2$ restores the capacity of $\mathrm{C} 2$ -

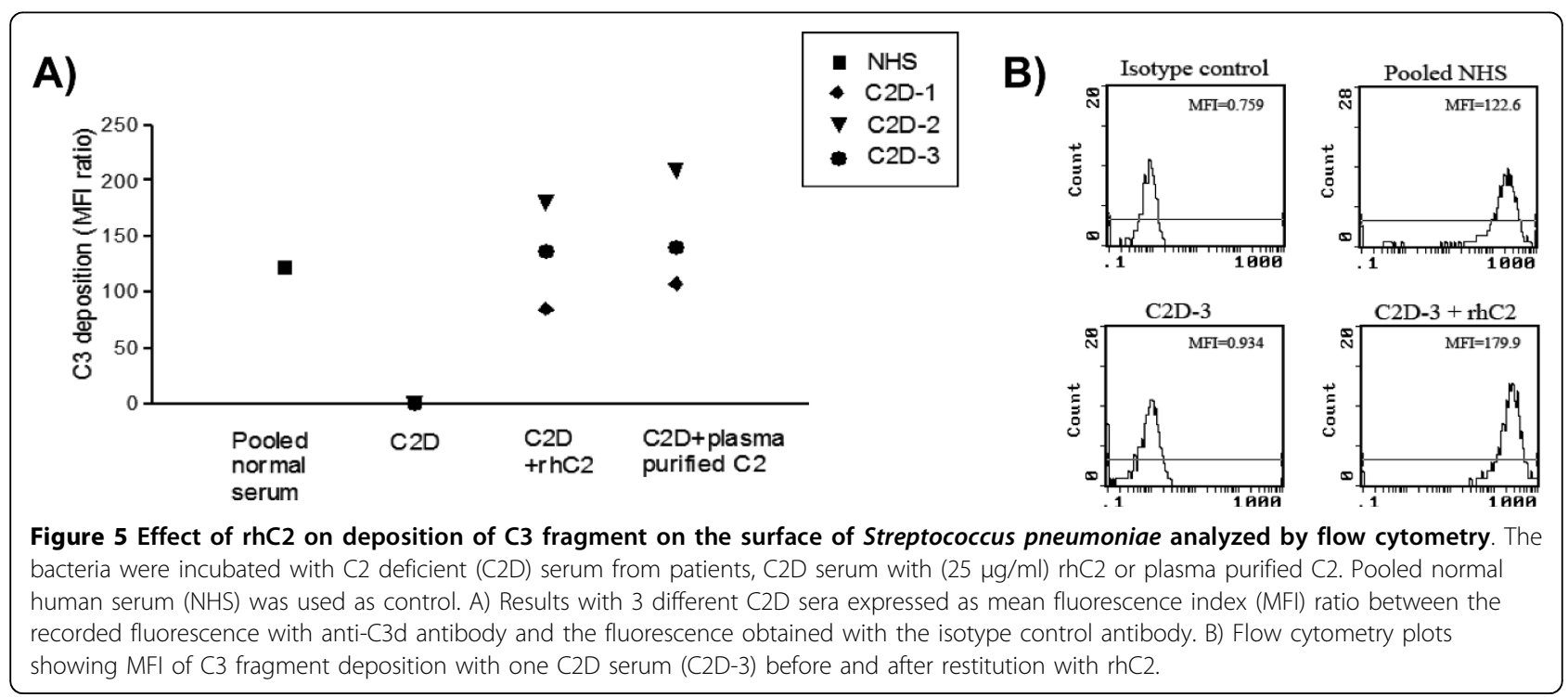




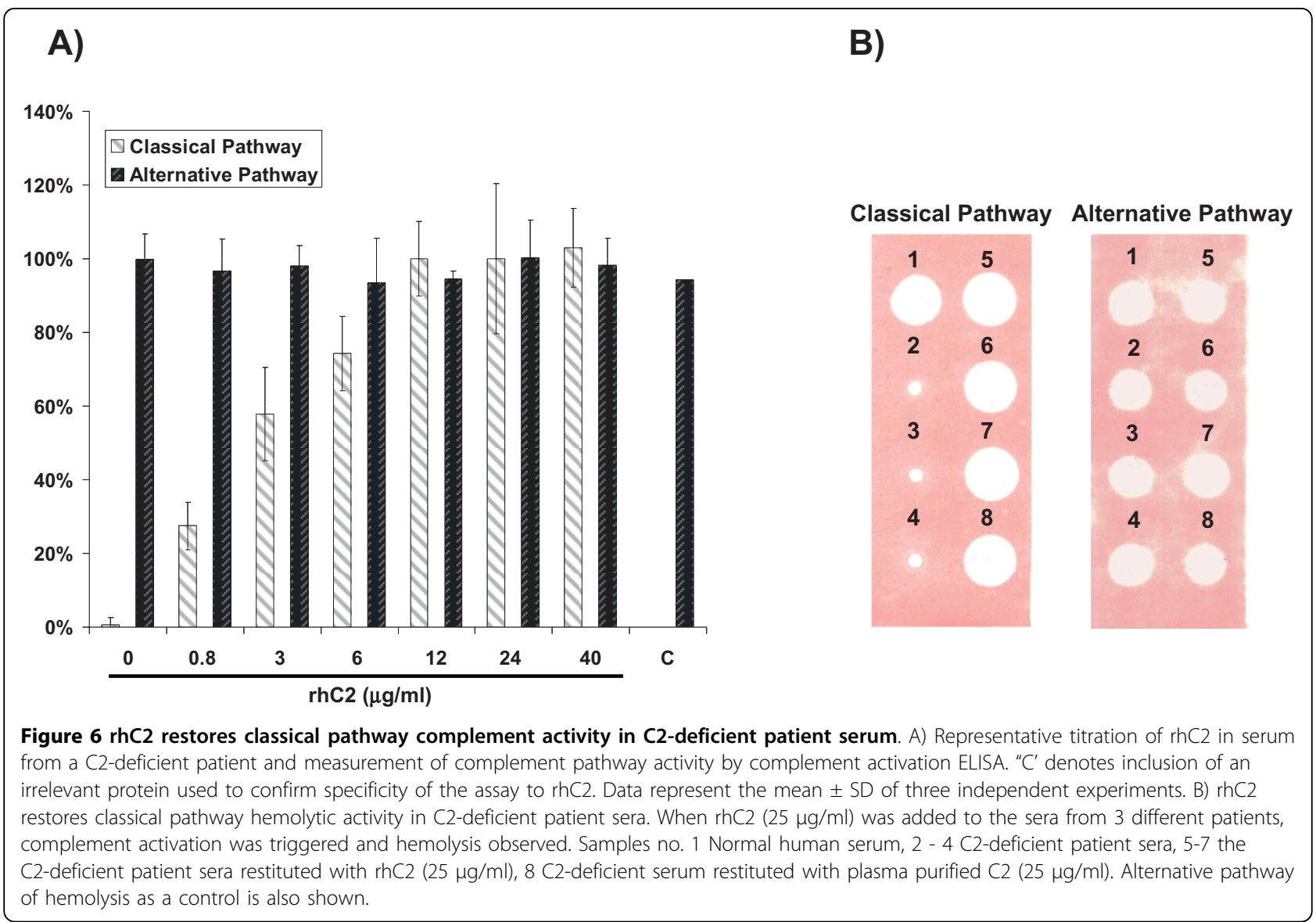

deficient patient serum for classical pathway activation enabling the formation of the MAC (Figures 6A and $6 \mathrm{~B})$. Titration of $\mathrm{rhC} 2$ revealed that a concentration of $3.0-6.0 \mu \mathrm{g} / \mathrm{ml}$ was sufficient to activate the classical complement pathway to $\geq 70 \%$ activity of normal human serum in different $\mathrm{C} 2$-deficient patient sera (Figure 6A). As a reference, normal human serum from healthy individuals contains $16-40 \mu \mathrm{g} / \mathrm{ml}$ of circulating C2. No activation of the lectin pathway was observed in most of these patient sera due to low serum levels of MBL (Table 1).

\section{Discussion}

In this study we provide proof of concept that rhC2 produced in human cells could be considered as an alternative treatment for $\mathrm{C} 2$-deficient diseases. This concept was originally formulated by Ruddy et al [11], where in an ex-vivo experiment they reconstituted hemolytic activity of $\mathrm{C} 2$-deficient serum collected from a patient by adding $\mathrm{C} 2$ purified from normal human serum. We have expanded this concept further and have demonstrated that $\mathrm{rhC} 2$ can be expressed in high quantities from human cells. We have prepared highly purified rhC2, shown that it undergoes post- translational modification and that it is very stable. $\mathrm{rhC} 2$ is cleaved in-vitro by $\mathrm{C} 1 \mathrm{~s}$ protease generating the active subunit of $\mathrm{C} 2$ (C2a) necessary to form the $\mathrm{C} 3$ convertase $\mathrm{C} 4 \mathrm{~b} 2 \mathrm{a}$ and more importantly, it restores the classical and lectin pathways in C2-depleted and C2-deficient serum at different concentrations. The fact that we were able to show normalization of

Table 1 Restitution of Classical (CP), Lectin (LP) and Alternative pathway (AP) activation in serum from 6 C2-deficient patients by addition of rhC2

\begin{tabular}{llll}
\hline $\begin{array}{l}\text { Restituted serum } \\
\text { Patient no. }\end{array}$ & CP & LP $^{\mathbf{c}}$ & AP \\
\hline 1 & $+^{++^{\mathbf{b}}}$ & \pm & +++ \\
2 & +++ & - & +++ \\
3 & +++ & \pm & +++ \\
4 & +++ & + & +++ \\
5 & +++ & ++ & +++ \\
6 & +++ & - & +++ \\
\hline
\end{tabular}

${ }^{\mathrm{a}} \mathrm{rhC2}$ was added to C2-deficient serum, final concentration $25 \mu \mathrm{g} / \mathrm{ml}$.

${ }^{\mathrm{b}}$ Complement activation tested by ELISA. $+++=100 \%$ activation, $++=50 \%$, $+=20 \%,-=$ no activation.

${ }^{\mathrm{C}} \mathrm{LP}$ activity reflects the MBL concentration governed by MBL genotype.

Patient 5 is homozygous for the wild-type structural gene variant (genotype $\mathrm{A} / \mathrm{A})$, while the other patients are heterozygous for this allele. 
complement activation at concentrations of rhC2 (3-6 $\mu \mathrm{g} / \mathrm{mL}$ ) that are lower than those typically observed in normal human serum $(16-40 \mu \mathrm{g} / \mathrm{mL})$ is in accordance with the reports that the heterozygous C2-deficiency state is not a risk factor for disease [3], and confirms that the rhC2 is fully functional.

To our knowledge this is the first report to date describing the production, purification and functional activity of $\mathrm{rhC} 2$ produced in human cells. In previous reports $\mathrm{C} 2$ was either from plasma of human or animal origin or from mouse L-cells or monkey COS cells [14,19-23]. The advantage of expressing C2 in human cells is that it may result in a more naturally glycosylated protein; most likely very similar or identical to the human C2 secreted in normal individuals, which is, in our opinion, an important consideration for the development of a therapeutic protein. We have also shown that $\mathrm{rhC} 2$ restores the classical pathway activation in-vitro in C2-deficient serum obtained from six different patients. The use of $\mathrm{C} 2$-deficient human serum represents the proof of concept for therapeutic use of rhC2 as an alternative therapy for $\mathrm{C} 2$ deficiency-associated diseases. Restoration of the classical pathway in human $\mathrm{C} 2$-deficient serum with $\mathrm{rhC} 2$ could be an important step, for instance, in treating C2-deficient SLE patients refractory to current therapies. Interestingly, it has been previously reported in two patients that infusion of normal fresh frozen plasma as a source of complement $\mathrm{C} 2$ provided therapeutic benefit $[12,13]$. Immunological studies performed in one of these patients revealed that these infusions led to increased serum C2 levels, increased hemolytic activity, decreased immune precipitation and decreased circulating immune complexes $[13,24]$. Although it has been argued that the observed clinical effects of fresh frozen plasma were a result of multiple components in the plasma (Factor B, immunoglobulin, $\mathrm{MBL}$ ) other than $\mathrm{C} 2$, it has been demonstrated that treatment with IgG only in the amount corresponding to one course of plasma infusion [24] did not have any beneficial effect, suggesting that the key player in promoting complement activity through the classical pathway, was $\mathrm{C} 2$ alone. In addition, infusion of rhC2 may decrease the risk of developing adverse reactions compared to plasma infusion as plasma contains many proteins that may trigger different reactions in patients.

The therapeutic use of rhC2 could also be considered in the case of $\mathrm{C} 2$-deficient individuals with recurrent or invasive bacterial infections. It has been shown that $\mathrm{C} 2$ deficiency is associated with increased susceptibility to recurrent infections by encapsulated bacterial pathogens such as Streptococcus pneumoniae $[7,25,26]$. Complement activation resulting in opsonization of the bacteria with C3 fragments is an important defense mechanism which is impaired in C2 deficiency [27]. Therefore, we could envision rhC2 as an adjunct therapy to antibiotics, with the rhC2 facilitating phagocyte-mediated clearance of the pathogen by enabling full complement cascade activation.

Blood protein replacement therapy is well established in some clinical situations, for example, intravenous immunoglobulin in patients with antibody deficiencies or coagulation factors in the hemophilias and specific lysosomal hydrolases in lysosomal storage diseases [28]. Drotrecogin alpha, a recombinant form of activated protein $C$, is approved for use in sepsis and Diffuse Intravascular Coagulation. The only complement replacement therapy already established is in hereditary angioedema caused by $\mathrm{C} 1$-inhibitor deficiency. Plasmaderived $\mathrm{C} 1$-inhibitor is shown to be an efficient treatment [29] and recombinant C1-inhibitor is under clinical evaluation [30]. Another complement protein that has been tried as replacement therapy is MBL in patients with MBL deficiency and clinical disease, related to the deficiency. Plasma-derived MBL has been used [31] and recently recombinant MBL was shown to successfully restore the MBL activation pathway in vivo [32]. Thus, all together these examples suggest that $C 2$ replacement therapy could be considered for further evaluation of possible therapeutic use in humans. Recombinant human proteins offer many benefits over purified products from pooled human plasma, such as a lower risk of transmission of infectious diseases and higher batch-to-batch consistency [33]. Therefore, it was important to show that rhC2 can substitute for endogenously produced $\mathrm{C} 2$ in its immune and anti-infective effects. The present report shows that $\mathrm{rhC} 2$ is fully functional in vitro and can be considered for protein replacement therapy in $\mathrm{C} 2$ deficiency-associated diseases.

\section{Conclusions}

We have demonstrated that a biochemically well characterized recombinant human complement component $\mathrm{C} 2$ produced in a human cell line restores classical complement pathway activation in vitro, in serum from C2deficient patients. Establishing efficacy in specific animal models for SLE and infectious diseases will further validate this concept; although the present study provides the first evidence for protein replacement therapy as a treatment of diseases related to $\mathrm{C} 2$ deficiency.

\section{Methods}

\section{Cell culture and protein expression}

Complement component C2 (NM_000063) was cloned from a liver cDNA library (Invitrogen, Carlsbad, CA), and inserted into a plasmid carrying a collagen promoter (pX804) or into pCep4 (Invitrogen, Carlsbad, CA). 
HT1080 cells (CCL-121, ATCC, Manassas, VA) were grown and maintained in $\mathrm{CD}$ media $(50 \% \mathrm{CD}-\mathrm{CHO}$ and $50 \%$ CD-293) (Invitrogen, Carlsbad, CA) at $37^{\circ} \mathrm{C}$ in a $5 \%$ $\mathrm{CO}_{2}$ incubator. Stable transfections were carried out using electroporation ( $450 \mathrm{~V}$ with $250 \mu \mathrm{F}$ of capacitance and $30 \mu \mathrm{g}$ of plasmid DNA suspended in $750 \mu \mathrm{l} 1 \times$ PBS). 293-F cells (Invitrogen, Carlsbad, CA) were grown in Freestyle 293 media (Invitrogen, Carlsbad, CA) containing GlutaMAX. Cells were transiently transfected using a polyethylenimine $(25 \mathrm{kD}$, Polysciences, Warrington, PA) to DNA ratio of 3:1 and were supplemented with $2.5 \mathrm{mg} / \mathrm{ml}$ Primatone (MP Biomedicals, Solon, $\mathrm{OH}$ ) at 24 hours. Seventy-two hours after transfection conditioned media enriched in rhC2 was harvested from a 25 liter wave bioreactor (GE Healthcare, Piscataway, NJ) and then processed for purification.

\section{Protein purification and biochemical characterization}

A two-step purification process was developed for $\mathrm{rhC} 2$. First a SP Sepharose Fast Flow resin column (GE Healthcare, Piscataway, NJ) was used to capture the protein from harvest medium. The binding capacity of the SP resin was experimentally determined by ELISA to be $0.37 \mathrm{mg}$ rhC2 per $\mathrm{ml}$ of SP resin. Protein was then eluted from the column and samples from collected fractions were analyzed by BCA Protein Assay Kit, (Pierce, Rockford, IL) to determine protein concentration and visualized by Coomassie staining (GelCode Blue Stain Reagent, Pierce, Rockford, IL) of 8-16\% trisglycine SDS-PAGE gels under reducing conditions (Invitrogen, Carlsbad, CA). The fractions containing full length $\mathrm{rhC} 2(102 \mathrm{kDa})$ were pooled and further purified over a Heparin Sepharose Fast Flow resin column (GE Healthcare, Piscataway, NJ). A binding capacity of $1 \mathrm{mg}$ of total protein by BCA assay per $\mathrm{ml}$ of Heparin resin was used. Eluted fractions were assessed as described above and those containing rhC2 were pooled, concentrated and buffer-exchanged into storage buffer $(10 \times$ PBS diluted to $1 \times$ in water and adjusted to $\mathrm{pH} 7$ ). Forty five liters of harvest media from the WAVE bioreactor yielded $228 \mathrm{mg}$ of purified $\mathrm{rhC} 2$. The resultant $\mathrm{rhC} 2$ protein was confirmed by $\mathrm{N}$-terminal sequencing (Mayo Proteomics Research Center, Mayo Clinic College of Medicine in Rochester, MN) and was assessed for purity using size exclusion chromatography. Purified rhC2 $(5 \mu \mathrm{g})$ was separated on a size exclusion chromatography (SEC) column (Tosoh SuperSW 3000, 10,000500,000 Da, Tosoh, Montgomery, PA) with $25 \mathrm{mM}$ sodium phosphate, pH 6.5 and $500 \mathrm{mM}$ sodium chloride in MilliQ water as the mobile phase with a flow rate of $0.15 \mathrm{ml} / \mathrm{min}$. The chromatogram was quantified using Exponential Skim Integration of the Empower software (Waters, Milford, MA). Using this procedure, the resultant rhC2 was determined to be $96 \%$ pure. The molecular weight and hydrodynamic radius of the major peak seen on size exclusion chromatography for rhC2 was analyzed using a multi angle static and dynamic light scattering system from Wyatt Technologies (Santa Barbara, CA) in conjunction with size exclusion chromatography method described above with the following modifications: the $\mathrm{pH}$ of the light scattering mobile phase buffer was increased to $\mathrm{pH} 7.0$, the flow rate was increased to $0.3 \mathrm{~mL} / \mathrm{min}$, and $10 \mu \mathrm{g}$ of $\mathrm{rhC} 2$ diluted $(1: 10)$ in light scattering mobile phase buffer.

Glycodigestion was performed to determine the presence of carbohydrates and sialic acid. Two micrograms of rhC2 was used for glycodigestion, for carbohydrate determination the protein was incubated for 1 hour and overnight at $37^{\circ} \mathrm{C}$ with Peptide $\mathrm{N}$-glycosidase in reaction buffer (New England Biolabs, Beverly, MA). For sialic acid determination, rhC2 was incubated for 1 hour at $37^{\circ} \mathrm{C}$ with neuraminidase in reaction buffer (New England Biolabs, Beverly, MA). SDS-PAGE was performed with $250 \mathrm{ng}$ of sample digested with above enzymes, loaded on $8-16 \%$ gel and visualized by Western blot. Thermal stability of rhC2 was assessed with differential scanning calorimetry using a MicroCal VP-DSC (GE Healthcare, Piscataway, NJ) with $400 \mu$ l buffer $(25 \mathrm{mM}$ sodium phosphate, $500 \mathrm{mM}$ sodium chloride) per buffer/sample pairs in 96 deep well plates loaded in the CapVP-DSC autoloader. Data were collected with the calorimeter scanning from 10 to $100^{\circ} \mathrm{C}$ at a rate of $60^{\circ} \mathrm{C}$ /hour.

A sandwich ELISA was developed to allow specific quantitation of rhC2 during purification. The wells of a 96-well Nunc Immuno plate (Nalge Nunc International, Rochester, NY) were coated with $100 \mu \mathrm{l}$ of $1 \mu \mathrm{g} / \mathrm{ml}$ antihuman C2 goat polyclonal antibody (R\&D systems, Minneapolis, $\mathrm{MN}$ ) in $50 \mathrm{mM}$ sodium bicarbonate, $\mathrm{pH}$ 9.6. The plate was sealed and incubated overnight at RT. The next morning the wells were washed 3 times with ELISA Wash Buffer (0.1\% Tween-20 in PBS), then $300 \mu \mathrm{l}$ of Blocking Buffer (PBS, 0.05\% Tween-20, 2\% BSA) were added to each well and the plate was incubated for 1 hour at $37^{\circ} \mathrm{C}$. Following the incubation, blocking buffer was removed, $100 \mu \mathrm{l}$ volume of samples and standards (pre-diluted in blocking buffer) were added to the plate, and the plate was incubated for 1 hour at $37^{\circ} \mathrm{C}$. Following incubation, the plate was washed as described above, the secondary antibody, a mouse anti-human $\mathrm{C} 2$ monoclonal antibody (Abcam, Cambridge, MA), was added to all wells at a final concentration of $1 \mu \mathrm{g} / \mathrm{mL}(100 \mu \mathrm{l}$ per well) and the plate was incubated for 1 hour at $37^{\circ} \mathrm{C}$ then washed. After washing, $100 \mu \mathrm{l}$ of $100 \mathrm{ng} / \mathrm{ml}$ of HRPconjugated anti-mouse antibody (Promega, Madison, WI) was added to each well and the plate was incubated for 1 hour at $37^{\circ} \mathrm{C}$ then washed. Finally, $100 \mu \mathrm{l}$ of the complete Peroxidase EIA Substrate Kit (BioRad, Hercules, 
CA) was added to each well and the plate incubated for $20 \mathrm{~min}$ at $37^{\circ} \mathrm{C}$. The reaction was stopped by adding $100 \mu \mathrm{l}$ of $2 \mathrm{~N} \mathrm{H}_{2} \mathrm{SO}_{4}$ to each well and the plate was read at $450 \mathrm{~nm}$ on a Molecular Devices plate reader equipped with SoftMax Pro software. The standard curve had a dynamic range from $200 \mathrm{ng} / \mathrm{ml}$ to $3 \mathrm{ng} / \mathrm{ml}$ prepared by serially diluting $\mathrm{C} 2$ purified from human serum (R\&D systems, Minneapolis, MN).

\section{Cleavage of rhC2 by $\mathrm{C} 1 \mathrm{~s}$}

rhC2 and purified $\mathrm{C} 2$ from human plasma at a concentration of $25 \mu \mathrm{g} / \mathrm{ml}$ and $50 \mu \mathrm{g} / \mathrm{ml}$, respectively were incubated with active $\mathrm{C} 1 \mathrm{~s}$ for $1 \mathrm{~h}$ at $37^{\circ} \mathrm{C}$ in veronal buffered saline with $0.15 \mathrm{mM} \mathrm{Ca}^{2+}$ and $0.5 \mathrm{mM} \mathrm{Mg}^{2+}$ (VBSCaMg) at a concentration of $70 \mu \mathrm{g} / \mathrm{ml}$ to induce complete cleavage of $\mathrm{C} 2$. $\mathrm{C} 1 \mathrm{~s}$ was produced and purified as described by Arlaud G.J. et al, [34]. The proteins were then analyzed by SDS-PAGE using NuPAGE ${ }^{\bullet}$ 4$12 \%$ Bis-Tris Gel, NuPAGE MES SDS running buffer (Invitrogen Carlsbad, CA) and visualized by Coomassie staining (Bio-Rad, Hercules, CA).

\section{Restoration of complement classical pathway}

The activity of purified rhC2 was determined using the Total Complement (3-pathway) ELISA (Alpco, Salem, $\mathrm{NH}$ ) according to manufacturer instructions. Pooled human serum that had been stripped of $\mathrm{C} 2$ by affinity purification (EMD BioSciences, San Diego, CA) was reconstituted with various concentrations of $\mathrm{rhC} 2$ and tested. The functional activity of $\mathrm{rhC} 2$ was also analyzed by hemolysis in gel assays that detect deficiencies in the classical and alternative pathways of complement activation as well as deficiencies in the terminal sequence. In the classical pathway assay antibodycoated sheep red blood cells were suspended in $0.6 \%$ agarose $\left(\right.$ SeaKem ${ }^{\mathrm{R}}$ ME agarose, Cambrex BioScience Rockland Inc., Rockland, ME) in the presence of $\mathrm{Ca}^{2+}$ and $\mathrm{Mg}^{2+}$. Guinea pig erythrocytes in the presence of $\mathrm{Mg}^{2+}$ and EGTA were used similarly in the assay for the alternative pathway. Samples were added to holes punched in the agarose in $5 \mu \mathrm{l}$ volumes and allowed to diffuse into the agar in moist atmosphere at $4^{\circ} \mathrm{C}$ for 18 hours and then at $37^{\circ} \mathrm{C}$ for 2 hours for the lytic reaction to proceed [18].

\section{Deposition of C3 fragments on bacteria}

Streptococcus pneumoniae 23F, obtained from Statens Serum Institut (Copenhagen, Denmark) were cultured on blood agar plates and then grown in Todd-Hewitt broth until log-phase was reached. The bacteria were harvested, washed in $0.15 \mathrm{M} \mathrm{NaCl}$ and killed by adding $0.8 \%$ glutaraldehyde in $0.15 \mathrm{M} \mathrm{NaCl}$ for $20 \mathrm{~min}$. The killed bacteria were stored in small aliquots at $-80^{\circ} \mathrm{C}$ until use. To measure C3 deposition on the bacteria, serum $(100 \mu \mathrm{l})$, diluted $1 / 20$ in $\mathrm{VBSCaMg}$, was added to $2.5 \mu \mathrm{l}$ bacteria and incubated for $30 \mathrm{~min}$ at $37^{\circ} \mathrm{C}$ with continuous agitation. The incubation was stopped by adding $500 \mu \mathrm{l}$ of ice-cold VBSCaMg. The bacteria were washed (centrifugation 2,880 $\times \mathrm{g}, 15 \mathrm{~min}$ ) and then $100 \mu \mathrm{l}$ of anti-C3d (Quidel, Santa Clara, CA), diluted 1/100 in VBSCaMg was added followed by an incubation at $4^{\circ} \mathrm{C}$ for $30 \mathrm{~min}$. After the incubation the bacteria were washed and resuspended in $100 \mu \mathrm{l}$ VBSCaMg and $5 \mu$ l FITC-conjugated polyclonal F(ab')2 rabbit anti-mouse immunoglobulins (DakoCytomation, Glostrup, Denmark) was added. The tubes were then incubated for $30 \mathrm{~min}$ at $4^{\circ} \mathrm{C}$. Prior to analysis by flow cytometry (Epics XL-MCL Beckman-Coulter, Fullerton, $\mathrm{CA})$, the bacteria were washed once and resuspended in $500 \mu \mathrm{l} \mathrm{VBSCaMg}$.

\section{C2-deficient patients}

Sera from 6 patients with homozygous C2 deficiency were used. Studies on the C2-deficient patients were approved by the Lund University Research Ethics Committee (LU 513-01) and written informed consent was obtained for each patient. The 6 individuals all had type I C2 deficiency as ascertained by DNA analysis, and had been reported earlier [7]. MBL genotypes had also been determined as reported [26]. Only one of these patients was homozygous for the wild-type variant of the structural MBL2 gene giving rise to high concentration of MBL and lectin pathway activity. The others were heterozygous for this allele and depending on promoter variants they showed lower concentrations of serum $\mathrm{MBL}$ to varying degrees.

\section{Abbreviations}

SLE: systemic lupus erythematosus; C2: complement component C2; rhC2: recombinant human complement component C2; MBL: mannose-binding lectin; MASP: MBL-associated serine protease; MAC: membrane attack complex; MALS: multi angle static light scattering; SEC: size exclusion chromatography; DSC: differential light scattering; PNGase-F: Peptide $\mathrm{N}$-glycosidase-F; MFI: mean fluorescence index.

\section{Acknowledgements}

We would like to thank our colleagues at Shire Human Genetic Therapies Inc., Kristin Davis, Kristen Meisner, Nicole Prince, Lisa M. Sturk and in particular Ann J. Barbier for her valuable intellectual contribution to this work.

Project funding was provided by Shire Human Genetic Therapies, Inc.

\section{Author details}

'Department of Protein Expression and Purification Research, Shire Human Genetic Therapies Inc., 700 Main Street, Cambridge, MA 02139, USA.

${ }^{2}$ Department of Infectious Diseases, Lund University Hospital, Klinikgatan 3, Lund 221 85, Sweden. ${ }^{3}$ Department of Laboratory Medicine, Section of Microbiology, Immunology and Glycobiology, Lund University, Solvegatan 23, Lund 223 62, Sweden. ${ }^{4}$ Department of Physiology, Shire Human Genetic Therapies Inc., 700 Main Street, Cambridge, MA 02139, USA. ${ }^{5}$ Department of Cell Culture Process Development, Shire Human Genetic Therapies Inc., 700 Main Street, Cambridge, MA 02139, USA. ${ }^{6}$ Department of Discovery, Shire Human Genetic Therapies Inc., 700 Main Street, Cambridge, MA 02139, USA. 


\section{Authors' contributions}

PGVM wrote the manuscript, AOT, PGVM, LT, JLP, MWH, MFC conceived and designed the experiments, LCC, SA, CB, JG, KIZ, NS, JL produced rhC2 and tested in-vitro, AWN, DML, SMF, KL purified and analyzed rhC2, GJ, CL, BG, LT provided patients serum and performed experiments. All the authors read and approved the final manuscript.

Received: 4 May 2010 Accepted: 20 August 2010

Published: 20 August 2010

\section{References}

1. Botto M, Kirschfink M, Macor P, Pickering MC, Wurzner R, Tedesco F: Complement in human diseases: Lessons from complement deficiencies. Mol Immunol 2009, 46:2774-83.

2. Figueroa JE, Densen P: Infectious diseases associated with complement deficiencies. Clin Microbiol Rev 1991, 4:359-95.

3. Pickering MC, Botto M, Taylor PR, Lachmann PJ, Walport MJ: Systemic lupus erythematosus, complement deficiency, and apoptosis. Adv. Immunol 2001, 76:227-324.

4. Walport MJ: Complement. First of two parts. N Engl J Med 2001, 344:1058-66.

5. Wallis R, Dodds AW, Mitchell DA, Sim RB, Reid KB, Schwaeble WJ: Molecular interactions between MASP-2, C4, and C2 and their activation fragments leading to complement activation via the lectin pathway. J Biol Chem 2007, 282:7844-51.

6. Tedesco F: Inherited complement deficiencies and bacterial infections. Vaccine 2008, , 26 Suppl 8: 13-8.

7. Jonsson G, Truedsson L, Sturfelt G, Oxelius VA, Braconier JH, Sjoholm AG: Hereditary C2 deficiency in Sweden: frequent occurrence of invasive infection, atherosclerosis, and rheumatic disease. Medicine (Baltimore) 2005, 84:23-34

8. Truedsson L, Alper CA, Awdeh ZL, Johansen P, Sjoholm AG, Sturfelt G: Characterization of type I complement C2 deficiency MHC haplotypes. Strong conservation of the complotype/HLA-B-region and absence of disease association due to linked class II genes. J Immunol 1993, 151:5856-63.

9. Wetsel RA, Kulics J, M-L Lokki, Kiepiela P, Akama H, Johnson CAC, Densen P, Colten HR: Type II human complement C2 deficiency. Allele-specific amino acid substitutions (Ser189 - > Phe; Gly444 - > Arg) cause impaired C2 secretion. J. Biol. Chem 1996, 271:5824-31.

10. Barilla-LaBarca ML, Atkinson JP: Rheumatic syndromes associated with complement deficiency. Curr Opin Rheumatol 2003, 15:55-60.

11. Ruddy S, Klemperer MR, Rosen FS, Austen KF, Kumate J: Hereditary deficiency of the second component of complement (C2) in man: correlation of $\mathrm{C} 2$ haemolytic activity with immunochemical measurements of C2 protein. Immunology 1970, 18:943-54.

12. Hudson-Peacock MJ, Joseph SA, Cox J, Munro CS, Simpson NB: Systemic lupus erythematosus complicating complement type 2 deficiency: successful treatment with fresh frozen plasma. Br J Dermatol 1997, 136:388-92.

13. Steinsson $\mathrm{K}$, Erlendsson $\mathrm{K}$, Valdimarsson $\mathrm{H}$ : Successful plasma infusion treatment of a patient with $\mathrm{C} 2$ deficiency and systemic lupus erythematosus: clinical experience over forty-five months. Arthritis Rheum 1989, 32:906-13.

14. Kerr MA, Porter RR: The purification and properties of the second component of human complement. Biochem J 1978, 171:99-107.

15. Nagasawa $\mathrm{S}$, Stroud RM: Cleavage of $\mathrm{C} 2$ by $\mathrm{C} 1 \mathrm{~s}$ into the antigenically distinct fragments $\mathrm{C} 2 \mathrm{a}$ and $\mathrm{C} 2 \mathrm{~b}$ : demonstration of binding of $\mathrm{C} 2 \mathrm{~b}$ to C4b. Proc Natl Acad Sci USA 1977, 74:2998-3001.

16. Bentley DR: Primary structure of human complement component $\mathrm{C2}$. Homology to two unrelated protein families. Biochem J 1986, 239:339-45.

17. Bork K, Horstkorte R, Weidemann W: Increasing the sialylation of therapeutic glycoproteins: the potential of the sialic acid biosynthetic pathway. J Pharm Sci 2009, 98:3499-508.

18. Truedsson L, Sjoholm AG, Laurell AB: Screening for deficiencies in the classical and alternative pathways of complement by hemolysis in gel. Acta Pathol Microbiol Scand [C] 1981, 89:161-6.

19. Davies KA, Erlendsson K, Beynon HL, Peters AM, Steinsson K, Valdimarsson $\mathrm{H}$, Walport MJ: Splenic uptake of immune complexes in man is complement-dependent. J Immunol 1993, 151:3866-73.
20. Fukuoka Y, Seino J, Okuda T, Tachibana T: Purification of the fourth, second and fifth components of mouse complement. Immunology 1984, 51:493-501.

21. Schultz DR, Arnold PI: Separation of functionally or highly pure C2 from human plasma with Sepharose and a lectin of Euonymus europeus. Acta Pathol Microbiol Immunol Scand Suppl 1984, 284:59-66.

22. Thielens NM, Villiers MB, Reboul A, Villiers CL, Colomb MG: Human complement subcomponent $\mathrm{C} 2$ : purification and proteolytic cleavage in fluid phase by C1s, C1r2-C1s2 and C1. FEBS Lett 1982, 141:19-24.

23. Wagner E, Platt JL, Howell DN, Marsh HC Jr, Frank MM: IgG and complement-mediated tissue damage in the absence of C2: evidence of a functionally active C2-bypass pathway in a guinea pig model. J Immunol 1999, 163:3549-58.

24. Erlendsson K, Traustadottir K, Freysdottir J, Steinsson K, Jonsdottir I, Valdimarsson $\mathrm{H}$ : Reciprocal changes in complement activity and immune-complex levels during plasma infusion in a C2-deficient SLE patient. Lupus 1993, 2:161-5.

25. Alper CA, Xu J, Cosmopoulos K, Dolinski B, Stein R, Uko G, Larsen CE, Dubey DP, Densen P, Truedsson L, et al: Immunoglobulin deficiencies and susceptibility to infection among homozygotes and heterozygotes for C2 deficiency. I Clin Immunol 2003, 23:297-305.

26. Jonsson G, Oxelius VA, Truedsson L, Braconier JH, Sturfelt G, Sjoholm AG: Homozygosity for the $\lg G 2$ subclass allotype $G 2 M(n)$ protects against severe infection in hereditary C2 deficiency. J Immunol 2006, 177:722-8.

27. Yuste J, Sen A, Truedsson L, Jonsson G, Tay LS, Hyams C, Baxendale HE, Goldblatt F, Botto M, Brown JS: Impaired opsonization with C3b and phagocytosis of Streptococcus pneumoniae in sera from subjects with defects in the classical complement pathway. Infect Immun 2008, 76:3761-70.

28. Neufeld EF: Enzyme Replacement Therapy. Lysosomal Disorders of the Brain. S.V Oxford University PressPlatt FMaW 2004, 327-338.

29. Kreuz W, Martinez-Saguer I, Aygoren-Pursun E, Rusicke E, Heller C, Klingebiel T: C1-inhibitor concentrate for individual replacement therapy in patients with severe hereditary angioedema refractory to danazol prophylaxis. Transfusion 2009, 49:1987-95.

30. Cugno M, Zanichelli A, Foieni F, Caccia S, Cicardi M: C1-inhibitor deficiency and angioedema: molecular mechanisms and clinical progress. Trends Mol Med 2009, 15:69-78.

31. Valdimarsson $\mathrm{H}$ : Infusion of plasma-derived mannan-binding lectin (MBL) into MBL-deficient humans. Biochem Soc Trans 2003, 31:768-9.

32. Petersen KA, Matthiesen F, Agger T, Kongerslev L, Thiel S, Cornelissen K, Axelsen M: Phase I safety, tolerability, and pharmacokinetic study of recombinant human mannan-binding lectin. J Clin Immunol 2006, 26:465-75.

33. Tabor E, Epstein JS: NAT screening of blood and plasma donations: evolution of technology and regulatory policy. Transfusion 2002 42:1230-7.

34. Arlaud GJ, Sim RB, Duplaa AM, Colomb MG: Differential elution of Clq, Clr and $\mathrm{Cls}$ from human $\mathrm{Cl}$ bound to immune aggregates. Use in the rapid purification of $\mathrm{Cl}$ subcomponents. Mol Immunol 1979, 16:445-50.

doi:10.1186/1471-2172-11-43

Cite this article as: Martini et al: Recombinant human complement component $\mathrm{C} 2$ produced in a human cell line restores the classical complement pathway activity in-vitro: an alternative treatment for C2 deficiency diseases. BMC Immunology 2010 11:43. 